Jurnal Konstruksi Hukum | ISSN: XXXX | E-ISSN: XXXX Vol. 1, No. 1, September 2020 Hal. 51-56| Available online at https://www.ejournal.warmadewa.ac.id/index.php/jukonhum DOI: https://doi.org/10.22225/jkh.1.1.2128.51-56

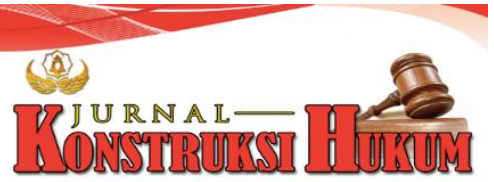

\title{
HAK-HAK TERSANGKA (MIRANDA RULE) PADA TAHAP PENYIDIKAN DALAM KITAB UU HUKUM ACARA PIDANA
}

\author{
Anak Agung Putu Surya Wiguna, I Made Sepud, I Nyoman Sujana \\ Fakultas Hukum Universitas Warmadewa, Denpasar-Bali, Indonesia
}

\begin{abstract}
Abstrak
Perlindungan hak-hak tersangka pidana sangatlah penting karena bagaimanapun tersangka merupakan orang yang kemerdekaan personalnya direbut akibat penangkapan, penahanan, penyitaan dan sebagainya. Oleh karena itu, hukum sangat diperlukan untuk menjamin pengambilan hak dari tersangka tersebut. Tujuan dalam penelitian ini yaitu untuk mengetahui pengaturan hak tersangka (Miranda Rule) pada tahap penyidikan dalam Kitab UU Hukum Acara Pidana dan membahas tentang perlindungan hukum terhadap hak-hak tersangka (Miranda Rule) pada tahap penyidikan. Penelitian ini menggunakan metode penelitian hukum normative dengan menggunakan pendekatan perundang-undangan dengan menelaah semua UU yang berhubungan dengan penulisan hak-hak tersangka (Miranda Rule) pada tahap penyidikan dalam KUHAP serta pendekatan konseptual dengan menggabungkan pendapat para ahli sehingga menjadi suatu argumentasi peneliti. Hasil penelitian menunjukan bahwa pengaturan hak-hak tersangka (Miranda Rule) pada tahap penyidikan dalam KUHAP adalah dtersangkatur dalam Pasal 1 ayat (14) KUHAP seseorang yang karena perbuatannya atau keadaannya, berdasarkan bukti permulaan patut diduga sebagai pelaku tindak pidana pengaturan Miranda Rule berlaku dalam Hukum Acara Pidana di Indonestersangka. Selain itu perlindungan hukum terhadap tersangka di tahap penyidikan secara eksplisit telah mencoba memberikan perlindungan untuk menghindari perlakuan kasar terhadap tersangka atau terdakwa. Sudah seharusnya para penyidik mengikuti aturan untuk menjelaskan hak-hak tersangka. Selain itu, perlu perhattersangkan khusus mengenai penegakan hukum di Indonestersangka, serta diharapkan tersangka harus lebih memahami hak-haknya sebagai tersangka agar dapat melakukan pembelaan kepada dirinya sendiri.
\end{abstract}

Kata Kunci: Hukum acara pidana, Miranda Rule, Penyidikan, Tersangka

\begin{abstract}
The protection of the rights of a criminal suspect is very important because after all the suspect is a person whose personal independence has been taken away as a result of arrest, detention, confiscation and so on. Therefore, the law is needed to guarantee the taking of rights from these suspects. The purpose of this research is to find out the arrangements for the rights of suspects (Miranda Rule) at the investigation stage in the Criminal Code Law and to discuss legal protection of the rights of suspects (Miranda Rule) at the investigation stage. This research uses a normative legal research method using a statutory approach by examining all laws related to the writing of the rights of suspects (Miranda Rule) at the investigation stage of the Criminal Procedure Code and a conceptual approach by combining expert opinions so that it becomes a researcher's argument. The results of the research show that the regulation of the rights of suspects (Miranda Rule) at the stage of investigation in the Criminal Procedure Code is suspected in Article 1 paragraph (14) of the Criminal Procedure Code for a person who due to his actions or circumstances, based on preliminary evidence, is reasonably suspected of being the perpetrator of a criminal offense, the Miranda Rule regulation applies in law. Criminal Procedure in Indonesia. Suspects. In addition, the legal protection of the suspect at the investigation stage has explicitly tried to provide protection to avoid harsh treatment of the suspect or defendant. Investigators should have followed the rules to explain the rights of suspects. Apart from that, special attention should be paid to law enforcement in Indonesia, and it is hoped that suspects must better understand their rights as suspects so that they can defend themselves.
\end{abstract}

Keywords: Criminal procedural law, Miranda Rule, Investigation, Suspect

\section{PENDAHULUAN}

Negara Amerika pada tahun 1963, terdapat pemuda yang bernama Ernesto Miranda ditangkap oleh Kepolistersangkan karena disangka melakukan penculikan dan pemerkosaan kepada seorang remaja perempuan yang berumur 18 tahun (Sunggono, 2001). Setelah itu, Ernesto Miranda ditangkap dan 
ditarik paksa menuju ruang introgasi. Ernesto Miranda selanjutnya menyampaikan pernyataan tertulis bahwa tersangka sudah melakukan penculikan dan pemerkosaaan kepada seorang remaja perempuan yang telah dimaksud sebelumnya. Akan tetapi, pada awalnya tersangka tidak diberitahu tentang hakhak nya khususnya untuk memperoleh bantuan hukum dengan tujuan untuk mendampingi didalam proses pemeriksaan. Pernyataan tersebut ditulisnya bertujuan untuk digunakan sebagai alat bukti pengakuan terdakwa, sehinggga tersangka dapat dipidana penjara selama 20 tahun (Lubis \& Haryanto, 2008).

Beberapa penelitian terkait dengan isu penelitian saat ini telah dilakukan sebelumnya seperti Ismail (2018) menunjukkan bahwa pemenuhan terhadap hak-hak tersangka merupakan ciri dari proses hukum yang adil yang berpijak pada rule of law. Selanjutnya, Hutapea \& Karianga (2019) menunjukkan adanya semangat yang sama antara Indonesia dan USA dalam menjunjung tinggi hak asasi manusia termasuk di dalamnya hak tersangka. Dengan persamaan tersebut memungkinkan dimasukannya "the right to remain silent" secara menyeluruh dalam hukum acara di Indonesia sebagimana yang berlaku di USA. Terakhir, Mapia (2018) mengatakan bahwa pendampingan penasehat hukum menurut KUHAP merupakan hak dari tersangka dan hak atas bantuan hukum atau hak tersangka didampingi penasihat hukum adalah wajib.

Aturan yang mengatur tentang hak-hak individu yang difitnahkan atau di sangkakan telah berbuat kejahatan atau pelanggaran disebut Miranda Rule (Lubis, 2010: 15). Miranda Rule ini didefinisikan sebagai suatu kewajiban penyidik untuk memberitahu hak-hak individu sebelum diperiksa oleh penyidik yang terbagi atas hak tidak membuat pernyataan secara lisan, dikarenakan seluruhnya dapat menjadi pemberatan di pengadilan, hak untuk mencari perlindungan hukum yang dibantu oleh advokat dan jika tidak mempunyai btersangkaya dapat diberikan advokat yang disedtersangkakan bukan olehnya (Sunggono, 2001). Hak tersangka sangatlah penting untuk diberi perlindungan oleh Hukum karena bagaimanapun tersangka merupakan orang yang haknya telah direbut secara paksa oleh karena itu hukum diperlukan untuk memberikan jaminan agar perampasan hak tidak dilakukan semena-mena (Arief, 2010).

Berdasarkan latarbelakang masalah di atas, maka penelitian baru ini bertujuan untuk mengetahui pengaturan hak tersangka (Miranda Rule) pada tahap penyidikan dalam Kitab UU Hukum Acara Pidana dan mengetahui perlindungan hukum terhadap hak-hak tersangka (Miranda Rule) pada tahap penyidikan.

\section{METODE PENELITIAN}

Penelitian ini menggunakan tipe penelitian normatif yang disebut juga penelitian hukum doctrinal. Alasan menggunakan tipe penelitian ini dikarenakan terdapat berbagai kendala-kendala saat melaksanakan Pasal 50 sampai dengan Pasal 63 KUHAP, tersangka ketidakadaan sanksi hukum yang jelas kepada proses peradilan, kekaburan sanksi yang dijatuhkan oleh aparat berwenang jika tidak dilakukan pasal 56 KUHAP dan adanya penolakan pendampingan penasehat hukum oleh terdakwa, dan halangan lainnya. Ini menyebabkan pelaksanaan dari pasal terebut didalam penerapannya, tersangka tergantung oleh aparat penegak hukum yang bersangkutan. Tipe penelitian ini merupakan penelitian yang berfokus pada masalah yang didasarkan pada teori. Dari sudut ilmu yang dipergunakan dalam penelitian ini bersifat monodisipliner dalam arti bahwa ada satu disiplin ilmu yang digunakan yaitu ilmu hukum. Pendekatan masalah dalam penelitian ini dilakukan dengan mempergunakan metode pendekatan perundang-undangan dengan menelaah semua UU dan regulasi yang bersangkut paut dengan peristiwa hukum yang terkait.

Dalam membahas tentang Hak Tersangka (Miranda Rule) pada tahap pemeriksaan tersangka ini menggunakan baham hukum. Bahan hukum yang dipakai dalam penelitian ini, yaitu bahan hukum primer yang merupakan bahan hukum yang memiliki kekuatan untk mengikat. Dalam penelitian ini meliputi, UU Dasar Negara Republik Indonesia Tahun 1945, UU No. 2 Tahun 2002 Tentang Kepolisian Negara Republik Indonesia, UU No. 39 Tentang Hak Asasi Manusia, UU No. 18 Tahun 2003 Tentang Advokat, UU No. 48 Tahun 2009 Tentang Kekuasaan Kehakiman, UU No. 8 Tahun 1981 Tentang Hukum Acara Pidana (KUHAP), dan berbagai instrument hukum lain yang relevan terkait Hak Tersangka (Miranda Rule) dalam tahap pemeriksaan tersangka. Bahan Hukum Sekunder, yaitu bahan hukum yang menjelaskan tentang bahan hukum primer yang didapat melalui pengkajian kepustakaan, meliputi buku-buku, jurnal- jurnal hukum, artikel yang berhubungan dengan Hak Tersangka (Miranda Rule) dalam tahap pemeriksaan tersangka. Bahan hukum tersier, adalah bahan 
hukum penjelasan dari bahan sekunder yang didapat melalui pencarian dalam kamus hukum, KBBI, ensiklopedia yang berhubungan dengan penelitian ini.

Untuk memperoleh bahan-bahan hukum primer, sekunder dan tersier digunakan teknik inventarisasi atau penelusuran bahan hukum yang bersangkutan lalu diklasifikasi atau dikelompokkan dan didokumentasikan, dicatat, dikutip, diringkas, diulas sesuai kebutuhan dengan pendekatan kualitatif. Setelah itu, data di analisis dengan menggunakan teknik sistematis dan disajikan secara deskriptif-analitis, yaitu menggunakan argumentasi yang bertumpu pada logika hukum dengan deduktif induktif.

\section{HASIL DAN PEMBAHASAN}

\section{Pengaturan Hak Tersangka (Miranda Rule) pada Tahap Penyidikan dalam Kitab UU Hukum Acara Pidana (KUHAP)}

Individu yang oleh perbuatannya berdasarkan bukti permulaan disangkakan sebagai pelaku kejahatan yang dapat kita sebut tersangka yang mengacu kepada pasal 1 ayat (14) KUHAP. Maka dari itu, tersangka individu yang melewati proses pemeriksaan permulaan, yang mana salah atau benarnya seorang tersangka wajib melewati proses peradilan yang baik dan jujur dengan mendahulukan asas persamaan dimuka hukum. Pada pasal 1 angka 14 KUHAP tidak secara terperinci diatur di dalam KUHAP. Namun KUHAP secara jelas menjelaskan tentang alat bukti yang sah di dalam ketentuan pasal 184 KUHAP. Dalam prosesnya dibolehkan alat bukti yang sah adalah keterangan saksi, keterangan para ahli dan surat. Sedangkan, alat bukti berupa petunjuk didapat dari pendapat hakim setelah melakukan proses pemeriksaan didalam peradilan, dan alat bukti berupa keterangan terdakwa didapat saat seorang terdakwa didalam proses peradilan sesuai dengan ketentuan pasal 188 ayat (3) KUHAP dan pasal 189 ayat (1) KUHAP.

Pada proses Penyidikan, penyidik tidak diperbolehkan memperlakukan tersangka dengan sewenang-wenang. Penyidik dalam proses penyidikan merupakan pejabat polisi atau aparatur sipil negara tertentu yang diberikan wewenang khusus oleh UU untuk melakukan penyidikan. Jika pada proses penyidikan tedapat laporan penyidik dan satu alat bukti yang sah maka dapat dijatuhkan status tersangka, dan yang dapat disebut alat bukti yang sah adalah keterangan saksi, keterangan ahli dan surat. Ada peraturan dalam bukti permulaan yang dimaksud Unus Testis Nullus Testis (satu saksi bukanlah saksi) adalah asas yang tidak menerima kesaksian tersangka hanya dari satu orang. Pada hukum acara perdata dan pidana, kesaksian tersangka seorang saksi tanpa adanya alat bukti lain, tidak diperbolehkan digunakan dan tidak dapat dipercaya sebagai dasar bahwa keterangan dari gugatan keseluruhan telah terbukti.

Kesaksian tersangka seorang saksi saja tidak begitu saja menjadi satu alat bukti yang sah, dikarenakan harus dibarengi dengan suatu alat bukti yang sah lainnya sesuai dengan ketentuan yang mengatur tentang alat bukti yang terdapat dalam KUHAP. Terhadap tersangka tersebut tidak dapat serta merta dikenai upaya paksa berupa penangkapan, karena telah ada syarat-syarat tertentu yang diatur dalam Perkap No. 14 Tahun 2012. Pasal 36 ayat (1) menyatakan tindakan penangkapan terhadap seorang tersangka hanya dapat dilakukan berdasarkan dua pertimbangan yang bersifat kumulatif (bukan alternatif).

\section{Perlindungan Hukum terhadap Hak-Hak Tersangka (Miranda Rule) Di Tahap Penyidikan}

Dalam Kitab Undang-Undang Hukum Pidana (KUHAP) menjelaskan dan mengatur mengenai pelindungan terhadap tersangka atau terdakwa agar mendapatkan perlakuan yang layak, yang mana telah disebutkan dalam pasal 52 KUHAP beserta penjabarannya yang dimana dalam kententuan undang- undang mewajibkan agar tersangka diperiksa dalam keadaan bebas dari rasa cemas yang sering kali mengarah pada akibat intimidasi dan perlakuan yang tidak baik oleh penyidik, meskipun dalam kententuan penyidik memiliki dasar hukum guna mencari kebenaran tentang perkara yang sedang dijalani oleh tersangka, dalam pemeriksaan tersangka yang mengacu pada pasal 52 disana dijelaskan bagaimana hak tersangka dalam memberikan kesaksian tersangka dalam pasal itu juga terdapat makna guna melindungi tersangka dalam memberikan kesaksian tersangka agar tidak merasa tertekan atau adanya paksaan dari tersangka dalam memberikan Kesaksian tersangka dalam proses pemeriksaan penyidik. Dalam Kitab Undang-Undang Hukum Pidana dalam pasal lainnya juga memberikan penjelasan mengenai hak yang diterima oleh pelaku kejahatan atau seseorang yang 
melawan hukum dimana dalam pasal lain dalam Kitab Undang-Undang Hukum Pidana tersangka diperbolehkan memberikan kesaksian tersangka secara bebas kepada penyidik.

Jika melihat penerapan hukum di Indonesia dimana hukum mengacu pada hak asasi manusia (HAM) maka tersangka dalam kasus apapun memiliki hak yang sama guna menjalankan kehidupan yang layak pasca kejadian yang menyeretnya atau menetapkan seseorang sebagai tersangka. Tersangka mendapatkan hak yang dimana telah diatur didalam undang-undang guna memberitahukan bahwa seseorang dapat dikatakan atau di tetapkan sebagai terangka juga memiliki hak yang sama di muka hukum, maka dari itu peranan Miranda Rule sangat penting guna menerapkan hukum di Indonesia khususnya ranah hukum pidana yang mana banyak kekerasan yang di dapat oleh para tersangka dan tidak sedikit juga seseorang yang di tetapkan sebagai tersangka tidak mendapatkan haknya dalam menjalankan atau baru memulai guna penyidikkan yang dilakukan oleh penyidik.

Hak yang berdasarkan dari hak asasi manusia juga menjadi dasar dalam pembetukan undangundang pidana dan dalam menjalankan hukum guna penegakan hukum di masyarakat hak asasi manusia berperan sangat penting yang menjadikan tersangka juga harus mendapatkan hak yang tidak melanggar hak asasi manusia. Setiap orang yang lahir merupakan anugrah dari Tuhan yang dimana tersangka orang atau manusia juga berhak mendapatka atau memperoleh hak guna mengembangkan diri. Dalam perkembangan diri yang dijalankan oleh setiap manusia, maka manusia tersebut harus berani mempertanggungawabkan perbuatannya di hadapan Tuhan Yang Maha Esa serta bertanggung jawab dihadapan hukum. Indonesia merupakan Negara yang menganut Negara hukum eropa continental yang dimana pergerakan masyarakat sesuai dengan aturan yang berlaku serta normanorma yang harus di terapkan dalam kehidupan bermasyarakat jika seseorang melanggar aturan yang di tetapkan maka seseorang tersebut dapat dikatakan melanggar hukum dan harus bertanggung jawab atas hukum yang sudah dilanggar.

Dalam peradilan negeri yang dimana menjalankan peradilan mengenai pelanggaran yang telah ditetapkan dengan aturan atau norma yang berlaku. Dalam peradilan pidana terdapat kamar khusus mengenai tersangka yang dimana tersangka memiliki hak yang sama sebagai warga Negara meskipun berstatus menjadi tersangka dalam peradilan. Miranda Rules sendiri merupakan produk hukum guna menjaga tersangka dari perbuatan yang tidak manusawi Miranda Rule lebih mengacu pada keikhlasan berdasarkan dengan fakta yang terjadi. Adanya Miranda Rules merupakan antisipasi dari tekanan yang di dapat tersangka ketika menjalani penyidikan. Pengakuan yang didapatkan ketika introgasi merupakan sebagai bukti bahwa terangka sudah mendapatkan peringatan secara tegas dan mahkamah juga menekankan pada penyidik dalam hal hasil introgasi penyidik tersebut. Yang dapat diartikan bahwa kesaksian tersangka yang diberikan kepada penyidik dapat digunakan tersangka untuk alat perlawanan di pengadilan, dan tersangka memiliki hak untuk mendapat pembelaan dari seorang ahli hukum guna mendapatkan haknya. Bahkan jika seorang tersangka tergolong sesorang yang tidak mampu berhak diberikan kuasa hukum oleh pengadilan guna mendapatkan haknya sebagai tersangka (Doyle, 2013).

Pada pengadilan tingkat pertama atau pengadilan yang berada di tingkat yang rendah dalam hal menanyakan untuk kebebasan yang akan berkurang secara signifikan dapat dilakukan dengan cara tes objektif yang dimana dikatakan sangat bekerja efisien guna mengetahui apakah seseorang tersebut kehilangan kebebasannya. Dalam tahap selanjutnya perihal introgasi atau yang disebut Miranda. Pengadilan harus memberikan penjelasan dan pemahaman kepada tersangka bahwa introgasi yang dilakukan berdasarkan aturan yang berlaku dan di jalankan oleh penegak hukum yang masih aktif. Mahkamah agung memberikan definisi tentang kata-kata dan tindakan pihak kepolisian yang dimana pihak polisi harus memberikan tanggapan yang pantas untuk dapat memberatkan tersangka dimana respon itu di lihat dari kesaksian tersangka dalam tahap penyidikan. Definisi tersebut dikeluarkan oleh mahkamah agung pada tahun 1980 yang bertujuan untuk tidak memberatkan tersangka dalam pengadilan (Medick, 2009).

\section{SIMPULAN DAN SARAN}

\section{Simpulan}

Berdasarkan hasil analisis di atas, maka dapat disimpulan bahwa (1) Pengaturan mengenai hak yang didapatkan tersangka dalam proses penyidikan tidak memberikan peraturan yang konkrit atau final jika di tinjau dari Kitab Undang-Undang Hukum Pidana tentang bagaimana urutan dalam melakukan penyidikan. Kitab Undang-Undang Hukum Pidana hanya memberikan penjelasan guna mencari 
kebenaran dalam pristiwa yang di hadapi oleh terangka dan mengumpulkan bukti agar terjadi singkronisasi dari kesaksian tersangka dan bukti yang dikumpulkan oleh penyidik dalam perkara yang dapat menyeret seseorang tersebut dan di tetapkan sebagai tersangka. Ditinjau dalam Peraturan Kapolri No. 14 Tahun 2012 tentang manajemen penyidikan tindak pidana, yang di dalam pasal 15 undang-undang tersebut mengatakan tersangka penyidikan diawali dengan urutan yang benar sesuai dengan undang-undang yang berlaku dari mulai proses penyelidikan, pengiriman surat pemberitahuan, dimulainya penyidikan (SPDP), upaya paksa, pemeriksaan, gelar perkara, penyelesaian berkas perkara, penyerahan berkas perkara ke penuntut umum. Penyerahan tersangka dan barang bukti; dan penghentian penyidikan. (2) Status tersangka yang di peroleh seseorang dalam tahap perlidungan hukum di tahap penyidikan secara eksplisit telah mencoba memberikan perlindungan untuk menghindari perlakuan kasar terhadap tersangka atau terdakwa, sebagaimana terdapat di dalam Pasal 52 KUHAP dan penjelasannya yang mengharuskan agar tersangka diperiksa dalam situasi bebas dari rasa takut atau ketakutan akibat intimidasi dan perlakuan kasar dari penyidik. Oleh karena itu, wajib dicegah adanya paksaan atau tekanan terhadap tersangka atau terdakwa. Kalau kita lihat juga dalam saat penyidikan akan dimulai, tersangka harus benar-benar dalam keadaan bebas dari rasa takut atau bebas dari intimidasi penyidik. Tegasnya tersangka tersebut harus benar-benar dalam keadaan bebas dari segala tekanan dalam bentuk apa pun baik fisik maupun psikis.

\section{Saran}

Melalu penelitian ini diharapkan kepada penyidik saat melakukan pemeriksaan, terlebih dahulu disampaikan dan dijelaskan hak-hak tersangka sebelum dilakukan penyidikan. Hal itu sangat penting untuk memberikan cerminan bahwa penerapan hukum di Indonesia sangat transparan sehingga tersangka tidak merasa tertekan dalam memberikan kesaksian atau tidak berada dalam tekanan penyidik. Pemberitahuan di awal sangat penting guna mempermudah tersangka dalam memberikan kesaksian terhadap kasus yang di hadapi yang menjadikan dirinya sebagai tersangka, Miranda Rule para tersangka dapat mengetahui haknya sebagai tersangka, maka dari itu sebelum dilakukan penyidikan alangkah baiknya bahwa penyidik memberikan pemahaman mengenai Miranda Rule memberikan hak tersangka saat proses penyidikan berjalan. Kemudian, kepada penegak hukum dalam melaksanakan kode etik Kepolisian Republik Indonesia perlu ditingkatkan agar penegak hukum tidak hanya memberikan sanksi kepada masyarakat tetapi juga memberikan sanksi kepada anggota kepolisian bagi yang melanggar Hak Tersangka (Miranda Rule) dan Kode Etik Kepolisian sehingga asas keseimbangan kepentingan dapat terwujud. Selanjutnya, diharapkan kepada tersangka harus lebih memahami hak-haknya sebagai tersangka agar dapat melakukan pembelaan kepada dirinya sendiri di muka pengadilan.

\section{DAFTAR PUSTAKA}

Arief, B. N. (2010). Masalah Penegakan Hukum dan Kebijakan Hukum Pidana dalam Penanggulangan Kejahatan. Jakarta: Kencana Prenada.

Doyle, C. (2013). Terrorism, Miranda, and Related Matters (Congressional Research Service No. $7-$ 5700).

Hutapea, P. K., \& Karianga, I. (2019). Prinsip Miranda Rules “The Right To Remain Silent” Dalam Perspektif Perbandingan Hukum. Media Iuris, 2(3), 393-406.

Ismail, M. (2018). Telaah Terhadap Konstruksi Proses Hukum yang Adil dalam Sistem Peradilan Pidana. Jurnal Hukum Ekonomi Syariah, I(I), 99-116.

Lubis, M. S. (2010). Prinsip "Miranda Rule" Hak Tersangka Sebelum Pemeriksaan. Yogyakarta: Pustaka Yustisia.

Lubis, M. S., \& Haryanto, M. (2008). Pelanggaran Miranda Rule. Yogyakarta: Juxtapose.

Mapia, A. P. (2018). Tinjauan Yuridis tentang Hak Tersangka untuk Mendapatkan Penasehat Hukum menurut Pasal 56 Ayat (1) KUHAP1. Lex Crimen, VII(10), 130-141.

Medick, F. (2009). Exporting Miranda: Protecting the Right against Self-Incrimination when U.S. Officers Perform Custodial Interrogations Abroad. Harvard Civil Rights-Civil Liberties Law Review, 44.

Sunggono, B. (2001). Hak Mendapat Bantuan Hukum. Bandung: Penerbit Mandar Maju.

Undang - Undang Dasar Negara Republik Indonesia Tahun 1945

Undang - Undang No. 8 Tahun 1981 Tentang KUHAP 
Undang - Undang No. 2 Tahun 2002 Tentang Kepolisian Negara Republik Indonesia Undang - Undang No. 39 Tahun 1999 Tentang Hak Asasi Manusia

Undang - Undang No. 18 Tahun 2003 Tentang Advokat

Undang - Undang No. 48 Tahun 2009 Tentang Kekuasaan Kehakiman 